\title{
Introducing Computing Now
}

\author{
George K. Thiruvathukal \\ Loyola University Chicago, gkt@cs.luc.edu
}

Follow this and additional works at: https://ecommons.luc.edu/cs_facpubs

Part of the Computer Sciences Commons

\section{Recommended Citation}

George K. Thiruvathukal, "Introducing Computing Now," Computing in Science and Engineering, vol. 11, no. 4, pp. 8-10, July/Aug. 2009, doi:10.1109/MCSE.2009.124

This Article is brought to you for free and open access by the Faculty Publications and Other Works by Department at Loyola eCommons. It has been accepted for inclusion in Computer Science: Faculty Publications and Other Works by an authorized administrator of Loyola eCommons. For more information, please contact ecommons@luc.edu.

\section{(c) (1) $\$ \odot$}

This work is licensed under a Creative Commons Attribution-Noncommercial-No Derivative Works 3.0 License. Copyright @ 2009 George K. Thiruvathukal 


\title{
INTRODUCING COMPUTING NOW
}

\author{
By George K. Thiruvathukal
}

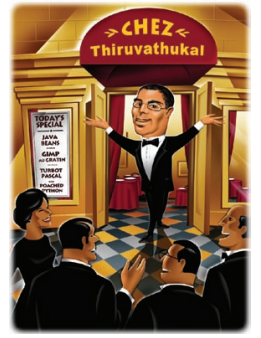

\author{
'M NOT EXACTLY SURE WHEN IT CAME TO PASS, BUT ROUGHLY A YEAR \\ AGO, NORMAN CHONACKY, OUR PREVIOUS EDITOR IN CHIEF, ASKED ME
}

TO SERVE AS A LIAISON TO THE IEEE COMPUTER SOCIETY'S COMPUTING

NOW PROJECT, A NEW INITIATIVE TO BRING TOGETHER ALL THE VARIOUS CS

publications online. Computing Now would amount to the fourth generation of initiatives to make the CS more Web savvy than ever, so it wasn't a role I embraced lightly or enthusiastically at first-if the previous three generations didn't succeed, why would the fourth time be a charm? Besides, I was happy editing the Scientific Programming department, which I had promised its previous editor, Paul Dubois, would be around for at least 20 more years.

\section{Surfing the Sea Change}

In any event, I knew Norman had his heart and mind in the right place and was fully aware of how important it was for us to be part of this initiative, knowing all too well the sea change happening in the magazine and print-publishing business, generally speaking. More important, we all care deeply about CiSE and know the important niche that it occupies. There really is no other publication like it, which is odd, considering how important all things computational are these days. We've been lucky to maintain, if not increase, our base of readers but know that many people have yet to discover all that this magazine has to offer. With Web 2.0 (going on 3.0), there's no doubt in my mind that more content from print publications will end up on the Internet (all or in part) or populating the growing phenomenon of truly "smart" phones and book readers such as Kindle. CiSE must determine how to be part of this uncertain but certain future because the Internet and mobile computing will dominate it. We must be able to maintain the same quality that goes into our print publication but perhaps not be as constrained in terms of the number of pages.

So exactly what is Computing Now, and why should you care about it? Here's a blurb about its original vision (taken from the "About" page at computingnow.computer.org):
Computing Now aggregates new print and online content from the IEEE Computer Society's 13 peer-reviewed magazines into one Web site. Each month, we highlight cross-magazine coverage of hot topics such as robotics, green computing, and social networking. Check back often, because we'll also be posting free articles and departments as each magazine goes to press. Participate in our From the Editors blog, and discover or subscribe to magazine-related multimedia content, such as news, podcasts, audio interviews, code snippets, and video demonstrations.

I copied the following text from our site because it comprises a proper subset of what we're currently doing with Computing Now, but you should view it as a starter set of ideas and not the end game:

- What's New: Free, newly published articles and departments from the IEEE CS's 13 magazines.

- Theme: Free monthly articles on hot topics, such as computer games and agile computing.

- From the Editors Blog: Perspective and opinions from our expert editors.

- Multimedia: Links to podcasts and video blogs.

- CS Newsfeed: Daily tech news updates.

- Book Reviews: Computing Now exclusive reviews of technology books, plus reviews from IEEE Software and IEEE Distributed Systems Online magazines.

- Survey: Voice your opinion on a different topic each week.

If you visit the Computing Now Web site, you'll notice that it has the look of a modern, socially focused portal that incorporates elements in its navigation or page sections much as you'd find on an established news sites. At 
the time of this writing, the current issue focuses on "Web 2.0 and Publishing," which coincides with our first-year anniversary (see http://www2.computer.org/portal/web/ computingnow/archive/may2009). Yours truly served as the guest editor for this theme, which features an introduction and several cross-cutting articles on this hot topic.

\section{The New Polylogue}

Since joining the Computing Now editorial board, however, much has changed. Or perhaps much has remained the same. As most of us know, the only constant on the Internet is change. Seemingly, a new idea-or variant on an old one-pops up just about every day. Twitter, for example, has taken a good part of the world by storm, with what appears to be the entire news media industry setting up its own Twitter feed. Many journalists and syndicated columnists see the writing on the wall and use Twitter.

But does Twitter matter? How long will the fun last? Who knows, but one thing is for certain: the publishing world is starting to rethink its traditional model and moving from monologue to dialogue (or should I say, polylogue). At least in part, "the press" is becoming more of a two-way (or $i$-way) medium, which is an unprecedented sort of change. During a recent email exchange with a friend of a friend who works as a food and wine columnist for The Chicago Tribune, I attempted to understand Twitter's attraction and how it has changed his life. He explained that having a large number of followers on Twitter means that he has more ideas for writing than he can handle, which is both a drawback and an opportunity. Invariably, this will lead to certain techniques to identify clusters or patterns, so that you (or marketers or whoever) can identify "what people are saying" without even reading the tweets. As a writer, I know that I would like to receive anonymous or personal tips for articles, so I'm starting to harness ideas via Twitter as well (follow me at gkthiruvathukal-I'd definitely like to hear from you). Luckily, the traffic is still low, probably because more people are interested in food and wine than computer/computational science. (But given that I'm interested in food and wine, too, maybe we're a strongly overlapping subset.)

As an editorial board, we're exploring numerous other opportunities as well, such as making it possible for readers to comment on articles. Indeed, readers do get in touch with us, but it's often at the level of individual email and tends to get buried in the inbox. Also, the notion of peer review should extend beyond the process that exists today-it's unrealistic to assume that a handful of readers will "catch all errors" in a publication so, inevitably, errors remain.
By allowing readers to post comments about opportunities for improvement, a published manuscript takes on a more dynamic life. It can help the original authors improve their work while simultaneously helping new authors (ok, emerging researchers) identify work with a "buzz" around it and take it in a new direction.

W e all know why we joined organizations such as the IEEE, the CS, the American Institute of Physics, and the ACM in the first place-doing so is part of maintaining a vital connection to our profession. However, these and other similar societies have all been slow to embrace emerging trends in social and professional networking. I see many professional computer scientists and engineers turning to sites such as LinkedIn for their needs. Isn't this where our professional societies are supposed to come in?

We can either develop our own infrastructure from scratch or take advantage of the best emerging practices, so we've set up Computing Now channels on Twitter, LinkedIn, and Facebook. It isn't clear whether all of these will stick, but in my opinion, these sites will have an impact when it comes to maintaining our connections. I talk to many people about social networking, and their responses range from skepticism to irrational exuberance. I tend to be in the camp that believes anything is possible, but I also know that being disengaged isn't likely to help CiSE or other CS publications move forward. Furthermore, our willingness to participate on such sites just might reach a new person who wants to know, "What's Computing Now?" or "What's CiSE?"

Only time will tell, but the attraction for me in being a part of CiSE in particular is that I have a great interest in both the theory and practice of computing and its intersections with other disciplines. We're an experimental bunch here. We're no strangers to applying experimental approaches when it comes to the content of this magazine. So why shouldn't we take the next steps and think about new ways to reach new readers? I'm sure those of you still reading to this point want to see CiSE continue to survive for the next 100 years-I like to think that these are the first steps. Join me on Twitter, and let me know what you think. I can always be reached by email, but we can all learn something as a community by trying something new.

George K. Thiruvathukal is an associate editor in chief for CISE magazine and is a member of the editorial board for Computing Now. You can follow him on Twitter @gkthiruvathukal or the "old fashioned" way at gkt@cisemagazine.org. 